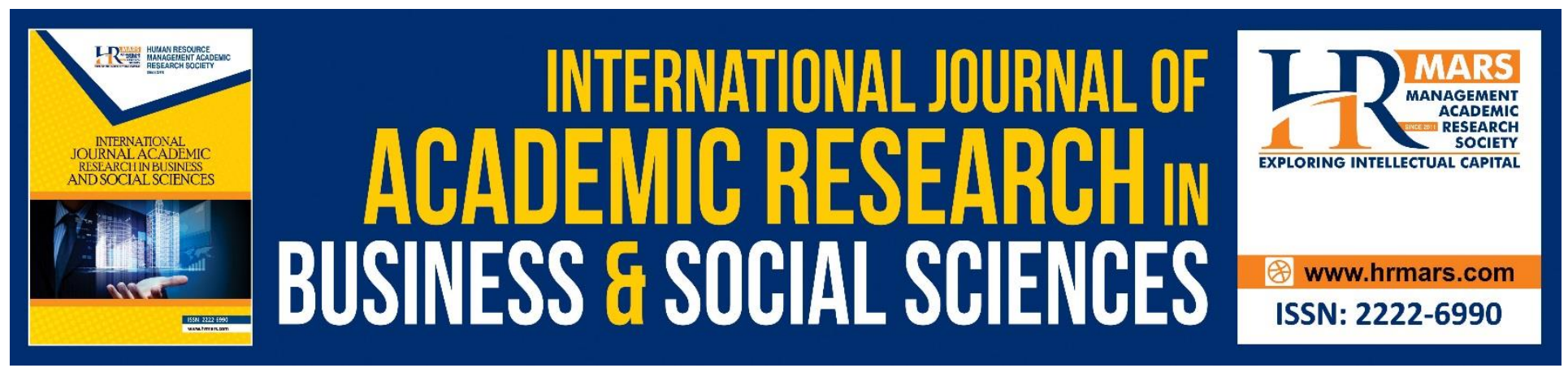

\title{
The Mediating Effect of Perceived Organizational Support between Talent Development and Employee Engagement at Malaysian GLCs
}

Aerni Binti Isa, Hazril Izwar Bin Ibrahim

To Link this Article: http://dx.doi.org/10.6007/IJARBSS/v10-i10/7531

DOI:10.6007/IJARBSS/v10-i10/7531

Received: 17 August 2020, Revised: 11 September 2020, Accepted: 30 September 2020

Published Online: 27 October 2020

In-Text Citation: (Isa, \& Ibrahim, 2020)

To Cite this Article: Isa, A. B., \& Ibrahim, H. I. B. (2020). The Mediating Effect of Perceived Organizational Support between Talent Development and Employee Engagement at Malaysian GLCs. International Journal of Academic Research in Business and Social Sciences. 10(10), 505-517.

Copyright: (c) 2020 The Author(s)

Published by Human Resource Management Academic Research Society (www.hrmars.com)

This article is published under the Creative Commons Attribution (CC BY 4.0) license. Anyone may reproduce, distribute, translate and create derivative works of this article (for both commercial and non-commercial purposes), subject to full attribution to the original publication and authors. The full terms of this license may be seen at: http://creativecommons.org/licences/by/4.0/legalcode

Vol. 10, No. 10, 2020, Pg. 505 - 517

http://hrmars.com/index.php/pages/detail/IJARBSS

JOURNAL HOMEPAGE

Full Terms \& Conditions of access and use can be found at http://hrmars.com/index.php/pages/detail/publication-ethics 


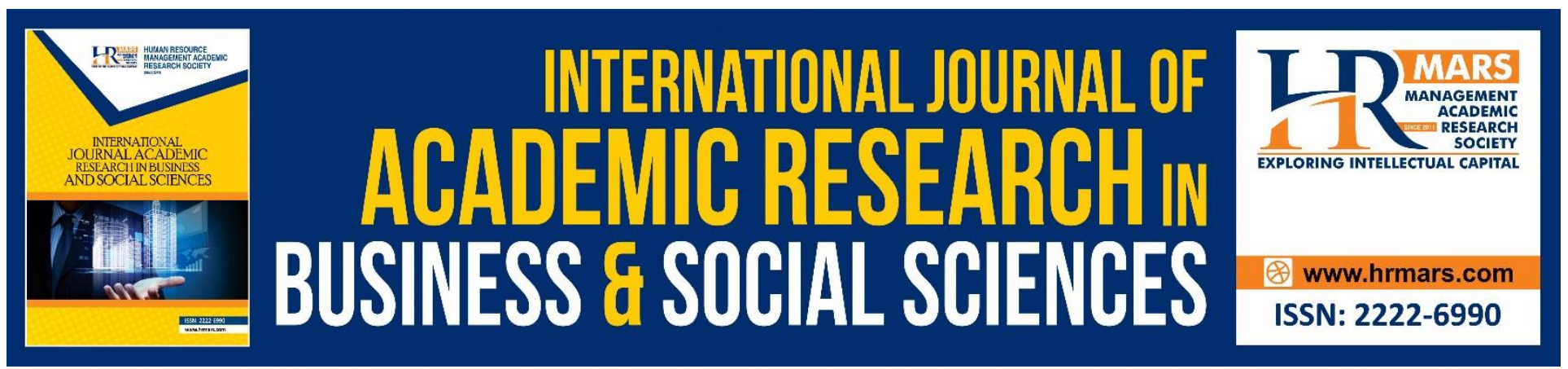

\title{
The Mediating Effect of Perceived Organizational Support between Talent Development and Employee Engagement at Malaysian GLCs
}

\author{
Aerni Binti Isa1, Hazril Izwar Bin Ibrahim² \\ ${ }^{1} \mathrm{PhD}$, School of Management, Universiti Sains Malaysia \\ ${ }^{2}$ Associate Professor, School of Management, Universiti Sains Malaysia
}

\begin{abstract}
The study analyzed the relationships between talent development, perceived organizational support and employee engagement among employees at Malaysian government-linked companies (GLCs). Questionnaires were distributed and gathered from 164 employees at 47 GLCs and Partial Least Squares Structural Equation Modeling (PLS-SEM) technique was used to test the research hypotheses. The findings discovered that all the hypotheses proposed in this study are supported. There were significant and positive relationships between talent development, perceived organizational support and employee engagement (vigor, dedication, absorption), and perceived organizational support significantly mediates between talent development and employee engagement. The results of the study suggest that talent development activities are crucial in improving the level of employee engagement at the workplace, which subsequently enable companies to sustain high productivity and gain competitive advantage.
\end{abstract}

Keywords: Talent Development, Vigor, Dedication, Absorption, Perceived Organizational Support.

\section{Introduction}

To compete and survive in a globalized economy, Malaysian government-linked companies (GLCs) require talents to add value to the organizations. Talent can be described as a person who holds extraordinary competences of strategic importance because they provide competitive advantages for the organization. Organizations need to have access to an internal talent pool for organizational growth to propel the organization for future competitiveness, and talent development has been identified as the instrument to enhance employees' knowledge, skills and capabilities. Malaysian government has identified the development of human capital in corporate business sector as an important factor that contributes to the country's economic growth (Bux, Ahmad \& Othman, 2009). The issues on development of talent at Malaysian GLCs are still ongoing while the empirical studies on the impact of talent management practices on perceived organizational support and employee engagement are still in its preliminary stage. 
INTERNATIONAL JOURNAL OF ACADEMIC RESEARCH IN BUSINESS AND SOCIAL SCIENCES Vol. 10, No. 10, 2020, E-ISSN: 2222-6990 @ 2020 HRMARS

\section{Problem Statement}

For the past decade, Malaysia has been losing skillful and experienced employees needed to drive future development as most of the skilled and experienced employees prefer to work abroad. According to statistics provided by the Ministry of Human Resources in 2008, more than 350,000 Malaysian adults are working abroad (National Economic Action Council, 2010). Such high competition in the job market is a pressing issue for Malaysian companies since there is a need to develop capable talent pool within the organizations to sustain their performance and compete in the challenging business environment.

Talent mismatches between skill demand and supply in job market and shortages of potential employees with the right expertise and employability skill, including transferability skills (PricewaterhouseCoopers Malaysia, 2013) have led to talent gap in many GLCs. Talent gap can be described as having insufficient skilled personnel in the organization, and if this issue is not addressed quickly, it will likely hamper the growth and development of the organizations. Without necessary skills related to their job, employees will not be able to carry their job properly and deliver their best performance, which lead to lower motivation and engagement level at the workplace. Talent development, as part of talent management practices, can help to reduce these skill gaps not only through formal trainings but also through other development tools such as apprenticeship, job rotation and exposure to various job environment and positions.

Training and development are essential for talents' career growth and training can provide them with all the required supports to deal with work-related challenges (Elnaga \& Imran, 2013). Providing comprehensive development program can be considered as a great support from the company to help employees to deliver better job quality and enhance their competencies, which greatly helps in improving the quality of workplace environment and increasing the level of work engagement.

\section{Research Question}

Based on the problem statement above, a set of research questions were developed:

RQ1: Is there a relationship between talent development and perceived organizational support ?

RQ2: Is there a relationship between perceived organizational support and employee engagement (vigor, dedication and absorption)?

RQ3: Does perceived organizational support mediate the relationship between talent development and employee engagement?

\section{Purpose of the Study}

Talent management practices are crucial for engaging employees in the organization and retaining crucial talents for GLCs to survive and compete in today's business world. In the context of talent development, each talent should be given the opportunity and support from the company for growth and development by giving them access of acquiring the necessary skills and competencies required to perform their roles effectively; this thus lead to improvement of employee engagement at the workplace. This study will uncover the role of perceived organizational support as the mediator on the relationship between talent development and employee engagement. Employee engagement in this present study is further characterized into 3 elements - vigor, dedication and absorption. 
INTERNATIONAL JOURNAL OF ACADEMIC RESEARCH IN BUSINESS AND SOCIAL SCIENCES Vol. 10, No. 10, 2020, E-ISSN: 2222-6990 @ 2020 HRMARS

\section{Talent Development}

Talent development is associated with extending knowledge, abilities, skills and competencies, and these are essential factors for fostering employee engagement and retaining talents (Stefko \& Sofka, 2014). Learning and development is an important aspect in an employee's career for building required competency to perform their daily tasks. Competent and highly skilled talents are needed for company to sustain their productivity and deliver strong business performance. Every talent has the potential to grow and an adequate support for development can strengthen employee's capacity in delivering their task.

Talent development encompasses wide range of skill building activities including on-the-job training, mentoring, job instruction training and other processes of developing competencies (Sheokand \& Verma, 2014). Another important and recommended approach/method on talent development is talent exposure. Through the process of exposure, talents have the opportunity to work in different environment, situation and context, and this can be conducted through job rotation and project assignment (Evans et al., 2011; as cited in Singh et al., 2017). Talent management practice promotes movement and deployment of employees around the organization structure to avoid career stagnation and feeling 'saturated' at work; this process can sustain high level of motivation, foster employee engagement and reduce rate of turnover. By exposing talents to various type of working environment, they will able to grow within the company, develop sense of belonging and stay in the company for a long period throughout their career (Jyoti \& Rani, 2014).

Through talent development programs, employees can continuously improve themselves while having better appreciation on company's core businesses, mission, and vision. A comprehensive talent development program should not only be focusing on competency enhancement of employees but also addressing their potential career growth within the organization. Focus on career growth and promotion to higher position lead to positive outcomes as talents feel that organization do care on their development and give support to them (Dries \& Pepermans, 2008).

\section{Employee Engagement}

Engaged talents feel empowered at workplace, they are able to develop strategies, make decisions and use their creativity to solve the given tasks; these employees are committed to their job, loyal and potentially more productive. They carry positive attitudes in themselves, work closely with others and are alert about the business environment (Theuri, 2017). Employee engagement is a vital instrument in increasing productivity at the workplace, enhancing level of motivation and reduce the attrition rates in a company. According to Kular, Gatenby, Rees, Soane \& Truss (2008), engaged employees will be more productive at work since they are more focused, not easily distracted and highly motivated, and these will bring positive outcomes to the organization (Harter, Schmidt \& Hayer, 2002). According to BlessingWhite (2006), employee engagement signifies the association of greater job satisfaction with maximum job contribution.

Schaufeli et al. (2002) defined employee engagement as a positive, fulfilling, work-related state of mind which can be further characterized into 3 elements - vigor, dedication and absorption. The first element, vigor, is described as being energetic and having psychological resilience while performing job, eager to put effort into the job and remain determined when facing challenges (Schaufeli et al., 
INTERNATIONAL JOURNAL OF ACADEMIC RESEARCH IN BUSINESS AND SOCIAL SCIENCES Vol. 10, No. 10, 2020, E-ISSN: 2222-6990 @ 2020 HRMARS

2002). An engaged talent is energetic and vigorous, bringing positive vibes to the workplace and stimulating high performance culture. The second element is dedication, which can be described as being involved with the work wholeheartedly and feeling the sense of importance, eagerness, encouragement, pride and achievement (Schaufeli et al., 2002). Dedicated employees are committed to their work, highly motivated and willing to be proactive and go the extra mile to accomplish job objectives, they deemed their roles and job outcomes as significantly impactful and meaningful. The last element of employee engagement is absorption; it is described as being fully immersed, giving full concentration and positively engrossed while performing one's job. Absorption at workplace can also be described as the feeling of enjoyment and pleasure in performing the task, of which time seems to pass quickly when one is enjoying what they do.

Gill (2007) explained that when a company provides all the necessary resources a per employee's expectation, such as access to improve competencies and fair career growth opportunities, they will be more engaged in their work, increase their productivity and develop sense of loyalty to the organization.

\section{The Relationship between Talent Development and Perceived Organizational Support}

Perceived organizational support is primarily important in maintaining the positive relationship between top management and the subordinate, and organization that offers support such as comprehensive personnel development may be seen as offering greater inducements to its staffs. This is supported by Tansky and Cohen (2001) who found positive link between employee development activities with perceived organizational support and organizational commitment. According to Allen et al. (2003), Dekker \& Barling (1995), Eisenberger, Rhoades \& Cameron (1999), Rhoades \& Eisenberger (2002) and Wayne et al. (1997), trainings are a part of the elements in perceived organization support.

Employees with high degree of perceived organizational support will feel morally obligated to repay the favorable treatment and motivated to contribute to the goals of the company. Talents who perceived high level of support from their company feel that they are being appreciated and closely attached to the business goals. This is supported by Kim et al. (2005), employees will develop strong sense of commitment and loyalty to the organization that is being supportive to them. Failure to accommodate employee welfare will negatively influence the employee's view of the organization.

Therefore, the following hypotheses are proposed:

$\mathrm{H} 1$ : There is a significant and positive relationship between Talent Development (TD) and Perceived Organizational Support (POS)

\section{The Relationship between Perceived Organizational Support and Employee Engagement}

Talent that perceived support from an organization will show high level of engagement in the workplace. Perceived organizational support is a "global belief concerning the extent to which the organization values employees' contribution and cares about their well-being" (Eisenberger, Huntington, Hutchnison \& Sowa, 1986) and is viewed as crucial in understanding job-related attitudes and behaviors of employees. The support from the organization lead to higher organizational 
INTERNATIONAL JOURNAL OF ACADEMIC RESEARCH IN BUSINESS AND SOCIAL SCIENCES Vol. 10, No. 10, 2020, E-ISSN: 2222-6990 @ 2020 HRMARS

commitment and decrease the intention to leave, and support from social surrounding and job autonomy are positively linked to employee engagement (Bakker et al., 2003).

If the employees perceive their organizations are supportive of their effort and, the end product of that will be most likely engaged employees in their jobs. An empirical study of banking employees in Bangladesh by Aktar and Pangil (2018) found that when employees are given the opportunities for proper career development and clear objectives and guideline about their work, they tend to recognize that the organization are concerned on their wellbeing and as a result, those employees exhibit higher level of motivation and become more engaged in their work. Talents' concerns on their career development can be addressed with the right implementation of talent management practices by human resource department (Tajuddin et al., 2014). When talents are receiving adequate support on trainings and development program, they will have more confidence on their job security and thus more engaged with their work (Aktar \& Pangil, 2018).

Through the supports from organization such as trainings and work exposure, talents are better equipped with skills and knowledge to perform their job more effectively. According to Ryan and Deci (2000), intrinsic motivation occurs when talents find their job interesting, and employees will enjoy doing their work more if they are competent and given autonomy to perform their job. Talents who perceived support from their companies are highly motivated, more energetic and demonstrating positive attitude at the workplace, and Dulagil (2012) found that employee engagement is closely linked to an employee motivation. When talents appreciate the support from the company, they give their full commitment on the job, passionate at their work and always put extra initiatives to deliver their work effectively. Gyekye and Salminen (2007) found employees perceiving supports from the organization to be more involved in their work and had stronger attachment to the organization. According to Truss et. al. (2013), employees that show high level of engagement will support the company in achieving organizational success; they are dedicated and deeply involved with their work. The study by Otineo, Wangithi and Njeru (2015) supported that employees who perceived support such as trainings and access to others resources related to the job are fully engaged and committed, they feel responsible to contribute back to the organization and develop sense of loyalty.

Therefore, the following hypotheses are proposed:

$\mathrm{H} 2$ : There is a significant and positive relationship between Perceived Organizational Support (POS) and Vigor (VIG)

H3: There is a significant and positive relationship between Perceived Organizational Support (POS) and Dedication (DD)

$\mathrm{H} 4$ : There is a significant and positive relationship between Perceived Organizational Support (POS) and Absorption (AA)

\section{Perceived Organizational Support as Mediator}

Talent management is best considered as a collective of mindset, tools and technologies that help organizations making good decisions about talented individuals, which significantly contributes to the success of the company (Creelman, 2004). Part of talent management activities focuses on developing talents' knowledge, skill and competency including exposing them to different working environment and rotating them around organization's structure to gain maximum experiences. 
INTERNATIONAL JOURNAL OF ACADEMIC RESEARCH IN BUSINESS AND SOCIAL SCIENCES Vol. 10, No. 10, 2020, E-ISSN: 2222-6990 @ 2020 HRMARS

Support for personnel development and growth are considered by employees as favorable treatment from the company in ensuring their well-being, and in turn they are returning the favor by delivering superior job performance and demonstrating strong attachment and dedication to the organization. According to findings by Ashar, Ghafoor and Munir (2013), employee trainings are positively associated with affective commitment and negatively affecting turnover intention. Another study by Nasurdin, Hemdi and Guat (2008) found positive mediation by perceived organizational support between employee development and organizational commitment.

To retain talents in the company, perceived organizational support is important in maintaining positive motivation in the workplace. Perceived organizational support motivates employees to work harder in achieving organizational goals (Eisenberger et al., 1986), they become more engaged in their job and bring positivity to the workplace. The right implementation of talent management practices is important in increasing the engagement levels of the employees at GLCs, and subsequently establish permanent competitive advantage (Lyria, 2014).

This study investigates the role of POS as a mediator (or intervening variable) between talent development (independent variable) and employee engagement (dependent variable). This study intends to prove that talent development will significantly affect POS as the mediator, and in turn positively affect the employee engagement. In absence of the mediator, talent development will also significantly affect the employee engagement. POS will have significant and unique effect on employee engagement.

The following hypotheses are generated based on literature reviews above:

H5: Perceived Organizational Support (POS) will significantly and positively mediate the relationship between Talent Development (TD) and Vigor (VIG)

H6: Perceived Organizational Support (POS) will significantly and positively mediate the relationship between Talent Development (TD) and Dedication (DD)

H7: Perceived Organizational Support (POS) will significantly and positively mediate the relationship between Talent Development (TD) and Absorption (AA)

\section{Research Methodology}

This study used non-probability sampling for data collection process, specifically the purposive sampling technique, where the data samples were collected from specific target groups of people who have the knowledge and experience to provide desired information (Sekaran and Bougie, 2013). The main variables of this study were talent development, perceived organizational support and employee engagement (vigor, dedication, absorption). The measurement items for talent development were adapted from studies by Cheese et al. (2008), Collings \& Mellahi (2009), Davies \& Davies (2010) and Mohan et al. (2015), while for the mediating variable perceived organizational support the study adapted and adopted measurement scale items established by Eisenberger et al. (1986). The dependent variables vigor, dedication and absorption under employee engagement were measured using the 9-item Utrecht Work Engagement Scale (UWES-9) from Schaufeli et al. (2006). All the items were anchored in a seven-point Likert Type Scale with values ranging between 1 and 7. 
INTERNATIONAL JOURNAL OF ACADEMIC RESEARCH IN BUSINESS AND SOCIAL SCIENCES Vol. 10, No. 10, 2020, E-ISSN: 2222-6990 @ 2020 HRMARS

The data collection process used self-administered questionnaires, where, 470 questionnaires were distributed to employees in 47 Malaysian GLCs via drop and collect method, and the duration for data collection for this study was 7 months. Out of 470 survey distributed, 164 valid responses were collected indicating 35\% response rate. The collected data were then analyzed using the Statistical Package for the Social Sciences (SPSS) Version 23 and Partial Least Square Structural Equation Modeling (PLS-SEM) software SmartPLS 3.0.

\section{Data Analysis}

The data was analyzed using the SPSS and SEM-PLS applications to prove the relationships between the independent, dependent and mediating variables. Table 1.1 and Table 1.2 below depicts the direct relationships between talent development, perceived organizational support and employee engagement's constructs (vigor, dedication, absorption), while Table 1.3 shows the relationships between the mediator, dependent and independent variables.

Table 1.1 Direct Effects of Talent Development on Perceived Organizational Support

\begin{tabular}{ccccccc}
\hline Hypothesis & Relationship & Beta & Std. Error & $\boldsymbol{t}$-values & $\boldsymbol{p}$-values & Decision \\
\hline H1 & TD $\rightarrow$ POS & 0.385 & 0.088 & $4.357^{* *}$ & 0.000 & Supported \\
\hline
\end{tabular}

Note. ${ }^{* *} \mathrm{p}<0.01(\mathrm{t}>2.33),{ }^{*} \mathrm{p}<0.05(\mathrm{t}>1.645)$ (based on one tailed test)

Table 1.1 above provides the detailed results of path coefficients, standard errors, $t$-values and $p-$ values for the direct effects of talent development and perceived organizational support. The results show that talent development had a strong effect on perceived organizational support.

Table 1.2 Direct Effects of Perceived Organizational Support on Employee Engagement (Vigor, Dedication \& Absorption)

\begin{tabular}{ccccccc}
\hline Hypothesis & Relationship & Beta & Std. Error & $\boldsymbol{t}$-values & $\boldsymbol{p}$-values & Decision \\
\hline H2 & POS $\rightarrow$ VIG & 0.501 & 0.082 & $6.116^{* *}$ & 0.000 & Supported \\
H3 & POS $\rightarrow$ DD & 0.560 & 0.070 & $8.024^{* *}$ & 0.000 & Supported \\
H4 & POS $\rightarrow$ AA & 0.521 & 0.069 & $7.605^{* *}$ & 0.000 & Supported \\
\hline
\end{tabular}

Note. ${ }^{* *} p<0.01(t>2.33),{ }^{*} p<0.05(t>1.645)$ (based on one tailed test)

The findings provided in Table 1.2 shows that perceived organizational support had positive relationships with all three constructs of employee engagement - vigor, dedication and absorption, with the strongest effect on dedication. 
INTERNATIONAL JOURNAL OF ACADEMIC RESEARCH IN BUSINESS AND SOCIAL SCIENCES Vol. 10, No. 10, 2020, E-ISSN: 2222-6990 @ 2020 HRMARS

Table 1.3 Mediating Effects

\begin{tabular}{ccccccccc}
\hline Hypothesis & Relationship & $\boldsymbol{\beta}$ & $\begin{array}{c}\text { Std. } \\
\text { Error }\end{array}$ & $\boldsymbol{t}$-values & $\begin{array}{c}\boldsymbol{p} \text { - } \\
\text { values }\end{array}$ & $\begin{array}{c}\text { Lower } \\
\text { Limit }\end{array}$ & $\begin{array}{c}\text { Upper } \\
\text { Limit }\end{array}$ & Decision \\
\hline H5 & TD $\rightarrow$ POS $\rightarrow$ VIG & 0.193 & 0.057 & $3.368^{* *}$ & 0.001 & 0.088 & 0.315 & Supported \\
H6 & TD $\rightarrow$ POS $\rightarrow$ DD & 0.215 & 0.062 & $3.494^{* *}$ & 0.000 & 0.100 & 0.342 & Supported \\
H7 & TD $\rightarrow$ POS $\rightarrow$ VIG & 0.201 & 0.057 & $3.493^{* *}$ & 0.000 & 0.096 & 0.320 & Supported \\
\hline
\end{tabular}

Note. ${ }^{* *} p<0.01(t>2.58),{ }^{*} p<0.05(t>1.96)$ (based on two- tailed test)

Table 1.3 shows that the hypothesis for $\mathrm{H} 5, \mathrm{H} 6$ and $\mathrm{H} 7$ were supported and there was a mediating effect of perceived organizational support in the relationships between talent development and employee engagement (vigor, dedication and absorption), verified by the t-values.

H5 was supported as the bootstrapping analysis showed that the indirect effect $\beta=0.193$ was significant with $t$-value of 3.368 (larger than 2.58) and p-value of 0.001 (smaller than 0.01). Besides, the $95 \%$ boot confidence interval (lower limit $=0.224$, upper limit $=0.555$ ) did not straddle a zero value in between, indicating that a mediating effect of perceived organizational support on the relationship between talent development and employee engagement's vigor. Similar results were also obtained for $\mathrm{H} 6$ and $\mathrm{H7}$, where the indirect effects were significant, and the $95 \%$ boot confidence interval did not straddle a zero value in between the lower and upper limit. Hence, the hypotheses were supported indicating a mediating effect of perceived organizational support between talent development and both dedication and absorption.

\section{Discussion}

The findings of this study provided evidence of a positive and significant relationships between talent development, perceived organizational support and employee engagement. The results also showed that perceived organizational support will positively and significantly mediate the relationships between talent development and employee engagement's constructs - vigor, dedication, and absorption. In other words, talent development is perceived as an important support from the company to strengthen employees' skills and knowledge, and it plays a pertinent role in enhancing employee engagement in the workplace. The results are further supported by previous studies which highlighted the positive influence of training and development on employee engagement (Atan, 2016; Rothmann \& Rothmann, 2010; Gebauer, 2006).

Development of talents can be both in terms of hard skills (specific measurable skill to perform certain job function i.e. technical proficiency) and soft skills (non-measurable skills like management and leadership skills). These competencies can facilitate employees to perform better and deliver better results, enabling them to earn faster promotions and have better earning position in the company. From the perspective of Self-Determination Theory (SDT), fulfilling employees' basic need for competency growth can effectively promote internal (intrinsic) motivation and positively affect their behavior at the workplace (Ryan \& Deci, 2000). When talents are highly motivated, they tend to reciprocate by showing greater dedication to the company, taking ownership of their roles, committed to the mission of the organization and passionate about their work. These qualities are 
INTERNATIONAL JOURNAL OF ACADEMIC RESEARCH IN BUSINESS AND SOCIAL SCIENCES Vol. 10, No. 10, 2020, E-ISSN: 2222-6990 @ 2020 HRMARS

crucial in a workplace environment to ensure high productivity and subsequently enable companies to sustain its competitive advantages.

There are several limitations in this study which can be further explored in future researches. Firstly, the scope of current study is limited to employees under talent pools of Malaysian GLCs. The scope of the study can be expanded to non-GLCs and private companies to gain broader perspective of talent development activities, as well as to remove any potential bias in the races, culture, salary scale and potentially the age limit considered for talent pool. Secondly, the scope of future studies can be expanded by looking into the talent development approach for different industries and job skills such as technical, non-technical and managerial positions.

\section{Theoretical Contribution}

This study provides invaluable insight and improved the understanding on the management on talent resources in the context of Malaysian employees. This study intends to discover new findings and contributions in different areas of talent management practices and its dimension especially on talent development and the mediating roles of perceived organizational support on employee engagement (vigor, dedication, absorption). The study provides deeper understandings on the concept of talent development and its relationship with employee engagement which is further supported by appropriate underlying theories.

The results of the study supported that in order for companies such as Malaysian GLCs to achieve superior performances and sustainable competitive advantages, they need to invest in and engage with their most valuable resources which is their employees; this is in line with the theory of Resource-Based View (RBV). In addition to that, the concept of talent development supports and satisfies the three psychological needs describes by SDT; the "need for competence" is satisfied by providing comprehensive programs to develop talents' all-round competencies, the "need for autonomy" is satisfied by giving talents freedom to customize and strategize their own development plans to meet their goals and career aspirations, and the "need for relatedness" is satisfied by encouraging talents to collaborate and working together with others in delivering the assigned projects or high-profile tasks.

\section{Practical Contribution}

The findings of this study help the GLCs to gain better understanding on the concept of talent development and its role in promoting employee engagement at the workplace. It provides managerial insights on the important factor to enhance employee engagement thus enabling them to optimize the capital management, allocate resources and operate efficiently. Organizations will be able to acknowledge the necessity of providing sufficient development program to their employees, not only to enable them to perform better at their job, but also to further motivate them to strive for the success of the firms and develop the sense of loyalty to the organizations.

As a conclusion, the findings of this study uncover the importance of talent development program in improving the level of employee engagement at the workplace. The contribution from this study will give significant practical implications on the management of talent resources in Malaysian GLCs. 
INTERNATIONAL JOURNAL OF ACADEMIC RESEARCH IN BUSINESS AND SOCIAL SCIENCES Vol. 10, No. 10, 2020, E-ISSN: 2222-6990 @ 2020 HRMARS

\section{References}

Ashar, M., Ghafoor, M. M., Munir, E., \& Hafeez, S. (2013). The Impact of Perception of Training on Employee Commitment and Turnover Intention: Evidence from Pakistan. International Journal of Human Resource Studies, 3(1), 74-88.

Atan, N. A. (2016). Organizational Culture, Human Resource Practices and Employee Engagement Among Academic Staff of Universiti Utara Malaysia (Master's Thesis). Universiti Utara Malaysia, Kedah, Malaysia.

Aktar, A., \& Pangil, F. (2018). Antecedents and Consequences of Employee Engagement: Conceptual Study. IOSR Journal of Business and Management (IOSR-JBM), 19(6), 54-67.

Bux, S. R., Ahmad, H. A., \& Othman, H. (2009). Talent Management Practices at Government-Linked Companies (GLCs). Retrieved from http://www.mpc.gov.my/wp-content/uploads/2016/04/ Talent-Management.pdf

Creelman, D. (2004). Return On Investment in Talent Management: Measures You Put to Work Right Now. Available from Human Capital Institute, 2121 K Street, N.W., Suite 800, Washington, D.C. 20037, USA.

Cheese, P., Thomas, R. J., \& Craig, E. (2008). The Talent Powered Organization: Strategies for Globalization, Talent Management and High Performance. London, England: Kogan Page Limited.

Collings, D. G., \& Mellahi, K. (2009). Strategic Talent: A Review and Research Agenda. Human Resource Management Review, 19, 304-313.

Davies, B., \& Davies, B. J. (2010). Talent Management in Academics. International Journal of Educational Management. 24(5), 418-426.

Dekker, I., \& Barling, J. (1995). Workforce Size and Work-Related Role Stress. Work and Stress, 9, 4554.

Dries, N., \& Pepermans, R. (2008). 'Real' High-Potential Careers: An Empirical Study into The Perspectives of Organisations and High Potentials. Personnel Review, 37, 85-108.

Dulagil, A. (2012). The Relationship of Employee Engagement and Well Being to Organization and Student Outcome. SBS HDR Student Conference Paper 1. University of Wollongong, Australia. Retrieved from https://ro.uow.edu.au/sbshdr/2012/papers/1/.

Eisenberger, R., Huntington, R., Hutchison, S., \& Sowa, D. (1986). Perceived Organizational Support. Journal of Applied Psychology, 71, 500-507.

Evans, P. A., Smale, A., Bjorkman, I., \& Pucik, V. (2011). Leadership Development In Multinational Firms, in Storey, J. (Ed.). Leadership in Organisations: Current Issues and Key Trends, London: Routledge.

Gebauer, J. (2006). Workforce Engagement - Learning and Development In China: Good for Workers; Even Better for Employers. Training \& Development, November 2006, 28-30.

Gill, D. S. (2007). Employee Selection and Work Engagement: Do Recruitment and Selection Practices Influence Work Engagement? (Unpublished Doctoral Dissertation). Kansas State University, Manhattan, Kansas.

Gyekye, S. A., \& Salminen, S. (2007). Workplace Safety Perceptions and Perceived Organizational Support: Do Supportive Perceptions Influence Safety Perceptions? International Journal of Occupational Safety and Ergonomics 2007, 13(2), 189-200. 
INTERNATIONAL JOURNAL OF ACADEMIC RESEARCH IN BUSINESS AND SOCIAL SCIENCES Vol. 10, No. 10, 2020, E-ISSN: 2222-6990 @ 2020 HRMARS

Harter, J. K., Schmidt, F., \& Hayes, T. (2002). Business-Unit-Level Relationship between Employee Satisfaction, Employee Engagement and Business Outcomes: A Meta-Analysis. Journal of Applied Psychology, 87(2), 268-279.

Schaufeli, W. B., Bakker, A. B., \& Salanova, M. (2006). The Measurement of Work Engagement with a Short Questionnaire: A Cross - National Study. Educational and Psychology Measurement, 66(4), 701-716.

Sekaran, U., \& Bougie, R. (2013) Research Methods for Business: A Skill-Building Approach. (6th ed.). New York: John Wiley \& Sons.

Stefko, R., \& Sojka, L. (2014). Position of Talent Management in Context of Organizational Functions. European Scientific Journal. Special Edition Vol.1, 346-356.

Kim, W. G., Leong, J. K., \& Lee, Y. K. (2005). Effect of Service Orientation On Job Satisfaction, Organizational Commitment, And Intention of Leaving in A Casual Dining Chain Restaurant. Hospitality Management, 24, 171-193.

Kular, S., Gatenby, M., Rees. C., Soane. E., \& Truss, K. (2008). Employee Engagement: A Literature Review (Working Paper). Kingston Business School, Kingston University, Kingston upon Thames, Surrey, UK.

Lyria, R. K. (2014). Effect of Talent Management on Organizational Performance in Companies Listed in Nairobi Securities Exchange in Kenya (Doctoral Dissertation). Jomo Kenyatta University of Agriculture and Technology, Nairobi, Kenya.

Mohan, M. D., Muthaly, S., \& Annakis, J. (2015). Talent Culture's Role in Talent Development among Academics: Insights from Malaysian Government Linked Universities. Journal of Contemporary Issues in Business and Government, 21(1), 46-71.

National Economic Advisory Council. (2010). New Economic Model for Malaysia Part 1. Retrieved from https://www.pmo.gov.my/dokumenattached/NEM_Report_I.pdf

Nasurdin, A. M., Hemdi, M. A., \& Guat, L. P. (2013). Does Perceived Organizational Support Mediate the Relationship Between Human Resource Management Practices and Organizational Commitment? Asian Academy of Management Journal, 13(1), 15-36.

Otieno, A. B. B., Wangithi, E., \& Njeru, A. (2015). Effect of Employee Engagement on Organizational Performance in Kenya's Horticultural Sector. International Journal of Business Administration, $6(2), 77-85$.

PricewaterhouseCoopers Malaysia. (2013). Future of Government Series - Redefining Human Capital For A Sustainable Future. Retrieved from https://www.pwc.com/my/en/assets/publications/future-of-govt-hc.pdf.

Ranganathan, C. M., Dhaliwal, S. J., \& Teo, S. H. T. (2004). Assimilation and Diffusion of Web Technologies in Supply Chain Management: An Examination of Key Drivers and Performance Impacts. International Journal of Electronic Commerce, 9(1), 47-61.

Rothmann, S., \& Rothmann Jr., S. (2010). Factors Associated with Employee Engagement in South Africa. SA Journal of Industrial Psychology, 36(2), 1-12.

Tajuddin, D., Ali, R., \& Kamaruddin, B.H. (2014). The Need of Talent Management as A Business Strategy for Malaysian Banking Institution. Australian Journal of Basic and Applied Sciences, 8(5), 69-74.

Tansky, J. W., \& Cohen, D. J. (2001). The Relationship between Organizational Support, Employee Development, and Organizational Commitment: An Empirical Study. Human Resource Development Quarterly, 12(3), 285-300. 
INTERNATIONAL JOURNAL OF ACADEMIC RESEARCH IN BUSINESS AND SOCIAL SCIENCES Vol. 10, No. 10, 2020, E-ISSN: 2222-6990 @ 2020 HRMARS

Jyoti, J., \& Rani, R. (2014). Exploring Talent Management Practices: Antecedents and Consequences. International Journal of Management Concepts and Philosophy, 8(4), 220248.

Wayne, S., L., Shore, L., \& Linden, R. (1997). Perceived Organizational Support and Leader- Member Exchange: A Social Exchange Perspective. Academy of Management Journal, 40(1), 82-111. 